\title{
Mast cells and multiple sclerosis in females and males
}

\author{
Per Gøran Krüger, Sverre Mørk \\ Institute of Biomedicine and Institute of Pathology, University of Bergen, Bergen, Norway \\ Email: per.kruger@biomed.uib.no
}

Received 13 December 2011; revised 15 January 2012; accepted 1 March 2012

\begin{abstract}
Mast cells were observed in autopsies from 11 females and 8 males. We confirm earlier observations that mast cells are more frequent in close vicinity to MSplaques. In these plaque-border zone areas, defined as the area within $1 \mathrm{~mm}$ distance of the actual plaques, the average number of mast cells was $2.34 / \mathrm{mm}^{2}$ in males and $4.77 / \mathrm{mm}^{2}$ in females, which in average is appr. 10 times more than earlier observed in MS. The difference in number of mast cells between females and males is significant $(p<0.005)$ and is of interest since females are more inclined to developing MS than males. Mast cells were rare in areas without visible plaques. The mast cells were preferably located close to capillaries and venules. A mechanism for the probable role of mast cells, based on diet-factors and mast cell mediators in the pathogenesis of MS is discussed.
\end{abstract}

Keywords: Mast Cells; Multiple Sclerosis; Quantification; Females; Males; Treatment

\section{INTRODUCTION}

Multiple sclerosis (MS) is an inflammatory demyelinating disease of the CNS. The presence of mast cells in border zones of plaques in multiple sclerosis have been confirmed by many scientists [1-7] and the significance of these observations have been evaluated [8-10]. The observation of elevated mast cell tryptase in cerebrospinal fluid of MS patients [11] supports the hypothesis that mast cells may be a functional element at the onset and in the maintenance of the MS disease process. The total numbers of mast cells observed has been low, approximately 1:100 that of normal skin [12], and therefore of most scientists suggested to be of no significance for the pathogenesis of MS. In the present investigation we studied the presence of mast cells in plaque/and normal appearing white matter from females and males dying after long periods with MS, employing immune-staining of the mast cell tryptase in autopsy samples, emphasizing differences in the numbers of mast cells in varying distances from MS-plaques.

\section{MATERIALS AND METHODS}

Brain tissue autopsies, kindly supported from Institute of Pathology, Haukeland university hospital, Norway and Aarhus hospital, Denmark, was collected from 19 patients (11 females and 8 males). No information was available as for the exact fixation time after death. Several (3 - 6) lesion samples were selected haphazardly from each of the cases. In all series a distinct plaque could be observed in at least one of the samples. All cases had been diagnosed with MS 4 - 8 years before they died of bronchopneumonia. The tissues were standardized fixed in $4 \%$ neutral formaldehyde, dehydrated and embedded in paraffin. The final paraffin-blocks had been stored 10 to 20 years before sectioned at appr. 7 um as in routine practice. For the precise identification of plaques, one series of sections were stained for myelin-basic protein or luxol-fast-blue. The total area of individual sections was registered using a G. Coradi (AG Zürich) planimeter. The total area of plaques within sections was registered employing a light microscope with area-calculation program equipped with a $2.5 \times$ lens.

One series of sections were DAB-stained (Dako chromogen System, Kode K3468) after immune-prosessing for human mast cell tryptase (Santa Cruz biotech. Mast cell tryptase (Fl-275): sc 32889). One series of sections were immuneprosessed twice: first with a kit (Vector Lab., Inc. Avidin/Biotin blocking kit sp-2001) for blocking biotin before immune-labelling, since biotin has been reported to be a significant source for false positive DABstaining in several tissues [13], and thereafter immune prosessed and DAB-stained for human mast cell tryptase.

Statistics: Students $t$-test.

\section{RESULTS}

\subsection{Effect of Blocking for Biotin}

No difference in the total numbers of mast cells could be observed with and without blocking for Biotin.

\subsection{Location of Mast Cells}

The majority of mast cells were observed in close apposition to capillaries and small and medium sized venules, 
in close apposition to the endothelium or in the adventitial layers (Figure 1).

\subsection{Significance of Data (Students $t$-Test) (Tables 1 and 2)}

\section{Mast Cells $/ \mathbf{m m}^{2}$ in Areas with No Visible Plaques.}

Females: $0.085+/-0.047(\mathrm{n}=4)$, males: $0.04+/-0.03$ $(\mathrm{n}=3)$. No significant difference between females and males.

\section{Mast Cells $/ \mathbf{m m}^{2}$ in Total Areas Including Plaques.}

Females: $0.16+/-0.15(\mathrm{n}=11)$, males: $0.091+/-0.04$ $(n=8)$. No significant difference between females and males.

Mast Cells $/ \mathbf{m m}^{2}$ in Border Zones (Defined as the Area Covering $1 \mathrm{~mm}$ outside and around Actual Plaque Area Observed).

Females: $4.77+/-3.86(\mathrm{n}=11)$, males $2.34+/-1.93$ $(\mathrm{n}=8)$. The difference between females and males is significant $(\mathrm{p}<0.005)$.

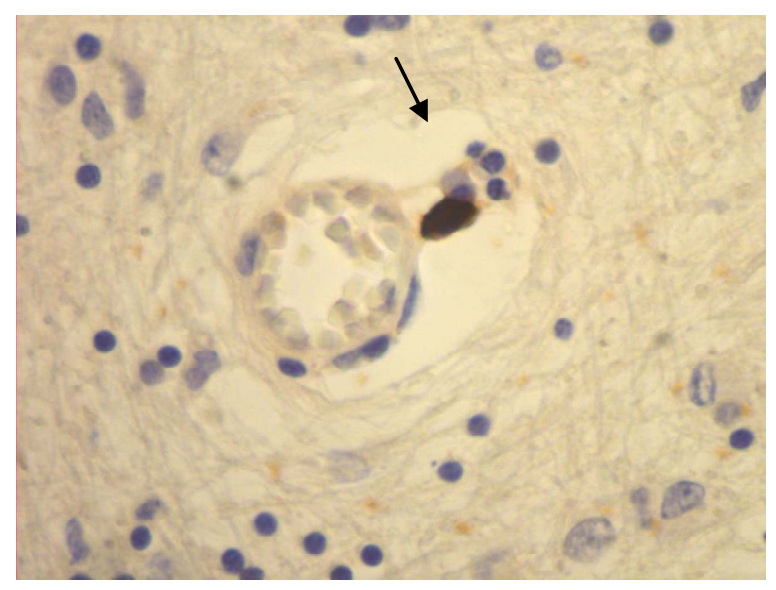

(a)

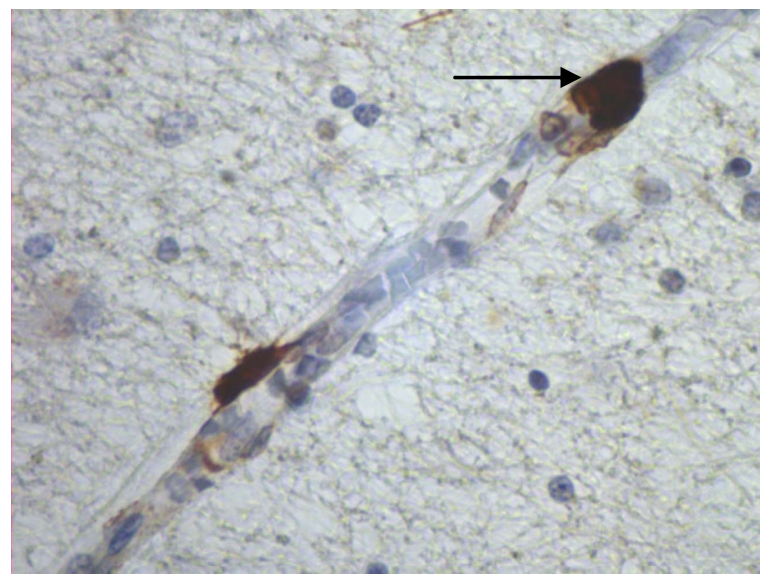

(c)

\section{DISCUSSION}

Multiple sclerosis has been described as an inflammatory and genetically determined disease.

As discussed elsewhere [8], MS is probably not genetically determined traditionally defined, although epigenetics $[14,15]$ and socio-dietary factors may explain effects of inherited lifestyles e.g. for MS. We do not know exact which dietary factors may be involved. Some decades ago, the frequency of MS was low in coastal areas of Norway, and, as discussed elsewhere $[2,12]$ the resent change in nutritional habits may explain why MS is now just as common in coastal as in inland communities. The diet was earlier based on the easy available protein and fat sources as various cod-fishes, herring and mackerel. Salmon and trout were in fact far too expensive for everyday consumption in these communities. Today the farmed salmon is cheap and easily available, but unfortunately the nutritional value has been questioned due to altered composition of their fatty acids [16-18], resulting from modern aqua-cultivation of salmon.

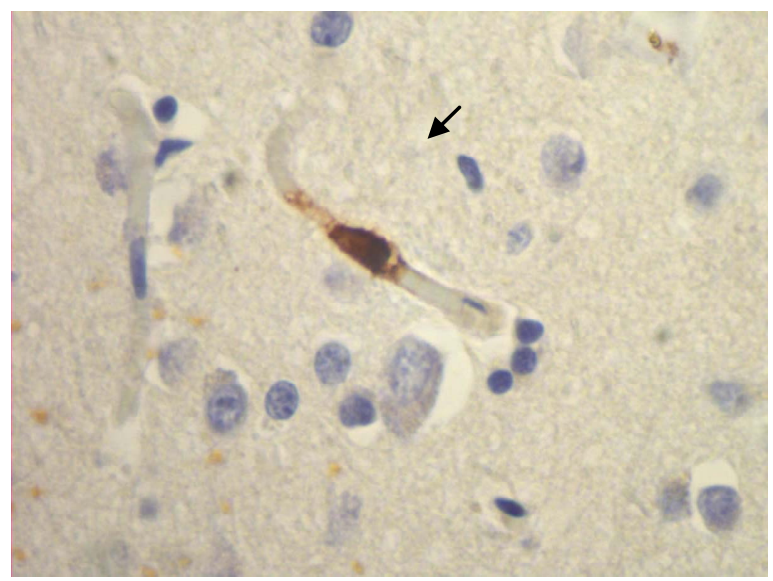

(b)

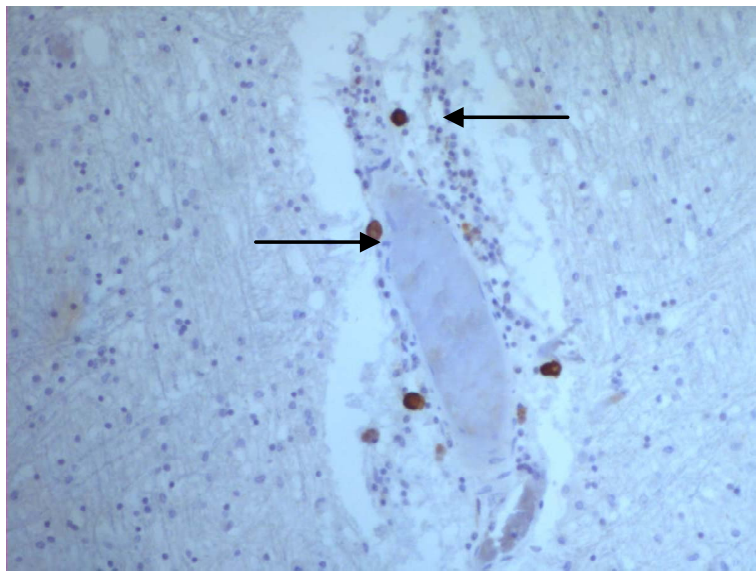

(d)

Figure 1. Mast cells (arrows) at capillaries: (a)-(c) all 400×, and venule (d) 100× in plaque lesions border zones of MS. 
Table 1. Numbers of mast cells in non-plaque- and plaque-border zone areas: females.

\begin{tabular}{|c|c|c|c|c|c|c|c|c|c|}
\hline \multicolumn{4}{|c|}{ Areas with no visible plaques } & \multicolumn{6}{|c|}{ Areas with plaques } \\
\hline Age & $\begin{array}{l}\text { Total area } \\
\text { observed } \\
\left(\mathrm{mm}^{2}\right)\end{array}$ & $\begin{array}{l}\text { Total } \\
\text { numbers of } \\
\text { mast cells }\end{array}$ & $\begin{array}{l}\text { Calculated } \\
\text { numbers of } \\
\text { mast cells } / \mathrm{mm}^{2}\end{array}$ & $\begin{array}{l}\text { Total area } \\
\text { observed } \\
\left(\mathrm{mm}^{2}\right)\end{array}$ & $\begin{array}{l}\text { Total plaque } \\
\text { area }\left(\mathrm{mm}^{2}\right)\end{array}$ & $\begin{array}{l}\text { Total area of } \\
\text { border zone }\end{array}$ & $\begin{array}{l}\text { Total numbers } \\
\text { of mast cells }\end{array}$ & $\begin{array}{l}\text { Calculated numbers } \\
\text { of mast cells } / \mathrm{mm}^{2} \\
\text { plaque border zone }\end{array}$ & $\begin{array}{l}\text { Calculated numbers } \\
\text { of mast cells } / \mathrm{mm}^{2} \\
\text { total area }\end{array}$ \\
\hline 30 & & & & 1050 & 29 & 22.2 & 74 & 3.3 & 0.07 \\
\hline 37 & & & & 400 & 3.6 & 9.9 & 22 & 2.2 & 0.06 \\
\hline 41 & & & & 880 & 36.9 & 24.7 & 353 & 14.3 & 0.4 \\
\hline 48 & & & & 650 & 38 & 25 & 38 & 1.5 & 0.06 \\
\hline 48 & & & & 710 & 58.7 & 30.7 & 162 & 5.3 & 0.23 \\
\hline 48 & & & & 730 & 24.1 & 20.5 & 22 & 1.1 & 0.03 \\
\hline 50 & & & & 540 & 125.9 & 42.8 & 256 & 6 & 0.47 \\
\hline 42 & 290 & 10 & 0.04 & 580 & 12.8 & 28.6 & 23 & 0.8 & 0.04 \\
\hline 45 & 300 & 19 & 0.06 & 1280 & 38.8 & 25.4 & 172 & 6.8 & 0.13 \\
\hline 49 & 880 & 119 & 0.14 & 270 & 0.8 & 6.3 & 29 & 4.6 & 0.1 \\
\hline 59 & 500 & 52 & 0.1 & 430 & 3 & 9.1 & 60 & 6.6 & 0.14 \\
\hline
\end{tabular}

Table 2. Numbers of mast cells in non-plaque- and plaque- border zone areas: males.

\begin{tabular}{|c|c|c|c|c|c|c|c|c|c|}
\hline \multicolumn{4}{|c|}{ Areas with no visible plaques } & \multicolumn{6}{|c|}{ Areas with plaques } \\
\hline$\overline{\text { Age }}$ & $\begin{array}{l}\text { Total area } \\
\text { observed } \\
\left(\mathrm{mm}^{2}\right)\end{array}$ & $\begin{array}{l}\text { Numbers of } \\
\text { mast cells }\end{array}$ & $\begin{array}{l}\text { Calculated } \\
\text { numbers of mast } \\
\text { cells } / \mathrm{mm}^{2}\end{array}$ & $\begin{array}{l}\text { Total area } \\
\text { observed } \\
\left(\mathrm{mm}^{2}\right)\end{array}$ & $\begin{array}{l}\text { Total plaque } \\
\text { area observed } \\
\left(\mathrm{mm}^{2}\right)\end{array}$ & $\begin{array}{l}\text { Total area of } \\
\text { border zone } \\
\left(\mathrm{mm}^{2}\right)\end{array}$ & $\begin{array}{l}\text { Total } \\
\text { numbers of } \\
\text { mast cells }\end{array}$ & $\begin{array}{l}\text { Calculated numbers } \\
\text { of mast cells/mm² } \\
\text { border zone }\end{array}$ & $\begin{array}{l}\text { Calculated numbers } \\
\text { of mast cells } / \mathrm{mm}^{2} \\
\text { total area }\end{array}$ \\
\hline 36 & & & & 830 & 20.2 & 19.1 & 82 & 4.3 & 0.1 \\
\hline 45 & & & & 320 & 12.5 & 15.7 & 4 & 0.3 & 0.01 \\
\hline 47 & & & & 370 & 27.7 & 21.8 & 43 & 2 & 0.12 \\
\hline 54 & & & & 400 & 33.9 & 23.8 & 43 & 1.8 & 0.11 \\
\hline 59 & & & & 330 & 32.4 & 22.7 & 29 & 1.3 & 0.1 \\
\hline 43 & 1040 & 26 & 0.03 & 260 & 20.8 & 19.3 & 16 & 0.8 & 0.1 \\
\hline 56 & 190 & 13 & 0.07 & 520 & 6.3 & 12 & 73 & 6.1 & 0.14 \\
\hline 79 & 1010 & 6 & 0.1 & 280 & 7.8 & 13 & 28 & 2.2 & 0.1 \\
\hline
\end{tabular}

As proposed by others $[19,12]$ the epigenetic effect of vitamin-D consumption by the mothers or grandmothers may be highly beneficial for the fetus, and may explain why MS was low in coastal areas since herring, mackerel and cod liver is high in vitamin-D [20].

The hypothesis that mast cells may be a cell element responsible for the onset, maintenance or enhancing factor in MS has generally been neglected. Their presence is hardly acknowledged, and the numbers are mostly assumed to be far too low to be of any significance. This neglect is partly due to improper staining procedures [3]. From the present investigation, it seems that the tracking of mast cells by the specific mast cell tryptase is more precise than other methods, and that the numbers of mast cells in close apposition to MS-plaques may be of significance.

The observation that total numbers of mast cells in the plaque border zones are higher in women than in men is of interest since females are more susceptible to developing MS than males [21]. Women even have a general higher incidence of inflammatory disorders than men [22]. These facts, as well as the finding that elevated concentrations of mast cell specific protease is present in the cerebrospinal fluid of MS patients [11], and the increase in mast cell transcripts within and outside MSlesions [23], supports the importance of mast cells for the onset and/or maintenance of MS. The report that histamine-1 receptor antagonist hydroxyzine, which partially inhibits brain mast cells, may reduce MS symptoms in females and males [24] further emphasises the importance of mast cells in MS.

The presence of mast cells in the plaque border zones may be secondary to a primary infection in the CNS, and the effect of mast cell mediators may be enhancement of an ongoing demyelinating process. Injection of estrogen in mice results in an increased number of mast cells [25], and the effect was most pronounced in females. The synergistic action of estradiol and myelin basic protein on mast cell secretion [26] supports the importance of sex hormones in the demyelinating process. In addition, women is shown to have more perivascular mast cells than men as e.g. in the skin $[27,28]$.

The primary secretagogue(s) for mast cells in CNS may be a metabolite (or several metabolites). Probably 
dietary factors produced in the CNS itself, alone or in combination with hormone(s) which triggers the mast cells to the release of potent mediators such as histamineinducing oedemas-and neutral proteases-dissolving myelin [29]. Neurotensine, substance P, ATP and catestatin may stimulate mast cells in experimental animal in vitro systems [30-33].

The possible immediate treatment of MS, based on the assumption that mast cells have some key-role, would be the application of mast cell blockers, to inhibit secretion of histamine and proteases and/or antihistamines as recently designed by others [24] to inhibit the histamineinduced oedema formation and protease induced demyelination. Local down-regulation of the blood-brain barrier leads to enhanced mediator access onto the perivascular mast cells. The fact that acute stress situations both stimulate mast cells and lead to exacerbation of MS [9, 34] further indicates importance of mast cells in the enigmatic disease multiple sclerosis.

In addition the increased consumption of vitamin-D, as e.g. fat fishes like herring and mackerel, would prevent $\mathrm{MS}$ in coming generation(s).

\section{CONCLUSION}

In summary, our observations that the number of mast cells is high in the border zones of MS-plaques, and that they are more plentiful in females than in males, may indicate that mast cells are implicated in the pathogenesis of multiple sclerosis.

\section{ACKNOWLEDGEMENTS}

We are indebted to Bodil Hansen and Ingrid Gavlen for excellent technical assistance.

\section{REFERENCES}

[1] Ibrahim, M.Z.M., Reder, A.T., Lawand, R., Takash, W. and Sallouh-Khatib, S. (1996) The mast cells of the multiple sclerosis brain. Journal of Neuroimmunology, 70, 131-138.

[2] Krüger, P.G. (2001) Mast cells and multiple sclerosis: A quantitative analysis. Neuropathology and Applied Neurobiology, 27, 275-280.

[3] Krüger, P.G., Bø, L., Myhr, K.M., Karlsen, Å.E., Taule, A., Nyland, H.I. and Mørk, S. (1990) Mast cells and multiple sclerosis: A light and electron microscopic study of mast cells in multiple sclerosis emphasizing staining procedures. Acta Neurologica Scandinavica, 81, 31-36.

[4] Neumann, J. (1890) Über das vorkommen der sogenannten mastzellen bei pathologischen veränderungen des gehirns. Virchows Arch, 122, 378-380.

[5] Olsson, Y. (1974) Mast cells in plaques of multiple sclerosis. Acta Neurologica Scandinavica, 50, 611-618.

[6] Theoharides, T.C. (1990) Mast cells: The immune gate to the brain. Life Sciences, 46, 607-617.

[7] Toms, R., Weiner, H.L. and Johnson, D. (1990) Identification of IgE-positive cells and mast cells in frozen sections of multiple sclerosis brains. Neuroimmunology, 30, 167-177.

[8] Krüger, P.G. and Nyland, H.I. (1995) The role of mast cells and diet in the onset and maintenance of multiple sclerosis: A hypothesis. Medical Hypotheses, 44, 66-69.

[9] Mohr, D. (2004) Association between stressful events and exacerbation in multiple sclerosis: A meta-analysis. British Medical Journal, 328, 731-733.

[10] Zappulla, J.P., Arock, M., Mars, L.T. and Liblau, R.S. (2002) Mast cells: Neurotargets for multiple sclerosis therapy? Journal of Neuroimmunology, 131, 5-20.

[11] Rozniecki, J.J., Hauser, S.L., Stein, M., Lincoln, R. and Theoharides, T.C. (1995) Elevated mast cell tryptase in cerebrospinal fluid of multiple sclerosis patients. Annals of Neurology, 37, 63-66.

[12] Gross, M. (2010) Piercing together the causes of lives torn apart. Oxford Today, 22, 20-21.

[13] Wang, H. and Pevsner, J. (1999) Detection of endogenous biotin in various tissues: Novel functions in the hippocampus and implications for its use in avidin-biotin technology. Cell and Tissue Research, 296, 511-516.

[14] Feinberg, A.P. (2007) Phenotypic plasticity and the epigenetics of human disease. Nature, 447, 433-440.

[15] Hayes, C.E., Cantorna, M.T. and De Luca, H.F. (1997) Vitamin D and multiple sclerosis. Proceedings of the Society for Experimental Biology and Medicine, 226, 21-27.

[16] Easton, M.D.L., Luszniak, D. and Von der Geest, E. (2002) Preliminary examination of contaminant loadings in farmed salmon, wild salmon and commercial salmon feed. Chemosphere, 46, 1053-1074.

[17] Hamilton, M.C., Hites, R.A., Schwager, S.J., Foran, J.A., Knuth, B.A. and Carpenter, D.O. (2005) Lipid composition and contaminants in farmed and wild salmon. Environmental Science \& Technology, 39, 8622-8629.

[18] Olsen, Y. and Skjervold, H. (1995) Variation in content of $\omega 3$ fatty acids in farmed Atlantic salmon, with special emphasis on effects of non-dietary factors. Aquaculture Internationale, 3, 22-35.

[19] Burell, A.M., Handel, A.E., Ramaqopalan, S.V. and Ebers, G.C. (2011) Epigenetic mechasnisms in multiple sclerosis and the major histocompatibility complex (MHC). Discovery Medicine, 11, 187-196.

[20] Bills, C.E. (1927) Antirachite substances. VI. The distribution of vitamin D with some notes on its possible origins. Journal of Biological Chemistry, 72, 751-758.

[21] Orton, S.M., Herrera, B.M., Yee, I.M., Valdar, W., Ramagopalan, S.V., Sadovnick, A.D. and Ebers, G.C. (2006) Sex ratio of multiple sclerosis in Canada, a longitudinal study. Lancet Neurology, 5, 932-936.

[22] Bjorling, D.E. and Wang, Z.Y. (2001) Estrogen and neuroinflammantion. Urology, 57, 40-46.

[23] Couturier, N., Zappulla, J.P., Lauwers-Cances, V., UroCoste, E., Delisle, M.-B., Clanet, M., Montagne, L., Van der Valk, P., Bö, L. and Liblau, R.S. (2008) Mast cell 
transcripts are increased within and outside multiple sclerosis lesions. Journal of Neuroimmunology, 195, 176-185.

[24] Logothetis, L., Mylonas, I.A., Baloyannis, S., Pashalidou, M., Orologas, A., Zafeiropoulos, A., Kosta, V. and Theoharides, T.C. (2005) A pilot, open label, clinical trial using hydroxyzine in multiple sclerosis. International Journal of Immunopathology and Pharmacology, 18, 771-778.

[25] Arvy, L. (1955) Effect of injection of estrogens on the mast cells of the white mouse. Nature, 175, 506.

[26] Theoharides, T.C., Dimitriadou, V., Letourneau, R., Rozniecki, J.J., Vliagoftis, H. and Boucher, W. (1993) Synergistic action of estradiol and myelin basic protein on mast cell secretion and brain myelin changes resembling early stages of demyelination. Neuroscience, 57, 861-871.

[27] Hellström, B. and Holmgren, H. (1947) En kvantitativ analys av mastcellsförekomsten I hud och hjärta hos människa. Svenska Läkartidn, 44, 617-630.

[28] Sundberg, M. (1955) On the mast cells in the human vascular wall. Acta Pathologica Microbiologica Scandinavica, 107, 1-81.

[29] Johnson, D., Seeldrayers, P.A. and Weiner, H.L. (1988) The role of mast cells in demyelination. I. Myelin proteins are degraded by mast cell proteases and myelin ba- sic protein and P2 can stimulate mast cell degranulation. Brain Research, 444, 195-198.

[30] Diamant, B. and Krüger, P.G. (1976) Histamine release from isolated rat peritoneal mast cells induced by adenosine-5-triphosphate. Acta Physiologica Scandinavica, 71, 291-302.

[31] Krüger, P.G., Mahata, S.K. and Helle, K.B. (2003) Catestatin (CgA344-364) stimulates rat mast cell release of histamine in a manner comparable to mastoparan and other cationic charged neuropeptides. Regulatory Peptides, 114, 29-35.

[32] Krüger, P.G., Aas, P., Onarheim, J. and Helle, K.B. (1982) Neurotensin-induced release of histamine from rat mast cells in vitro. Acta Physiologica Scandinavica, 114, 467469.

[33] Shanahan, F., Denburg, J.A., Fox, J., Bienenstock, J. and Befus, D. (1985) Mast cell heterogeneity: Effects of neuroenteric peptides on histamine release. The Journal of Immunology, 135, 1331-1337.

[34] Theoharides, T.C. and Cochrane, D.E. (2004) Critical role of mast cells in inflammatory diseases and the effect of acute stress. Journal of Immunology, 146, 1-12. 